\title{
Pengaruh Kompensasi Dan Lingkungan Kerja Terhadap Kepuasan Kerja Karyawan Pada PT. Temara Mas Sakti Di Jakarta
}

\author{
Damara Emily dan Carol Daniel Kadang \\ Program Studi Manajemen Fakultas Ekonomi dan Bisnis \\ Universitas Tarumanagara, Jakarta \\ E-mail: damaraemily29@gmail.com
}

\begin{abstract}
The purpose of this study is to explain and analyze the influence of compensation (X1) and work environment (X2) on employee job satisfaction (Y). Data was collected through distributing questionnaires to 50 employees PT. Temara Mas Sakti. Data processing techniques use Structural Equation Modeling (SEM) analysis with the help of SmartPLS. The results of this study indicate that compensation has a positive and significant effect on employee job satisfaction, work environment has a positive and significant effect on employee job satisfaction.
\end{abstract}

Keywords compensation, work environment, job satisfaction.

Abstrak: Tujuan dari penelitian ini adalah untuk menjelaskan dan menganalisis mengenai pengaruh kompensasi $\left(\mathrm{X}_{1}\right)$ dan lingkungan kerja $\left(\mathrm{X}_{2}\right)$ terhadap kepuasan kerja karyawan. Data dikumpulkan melalui penyebaran kuesioner kepada 50 karyawan PT. Temara Mas Sakti. Teknik pengolahan data menggunakan analisis Structural Equation Modeling (SEM) dengan bantuan SmartPLS. Hasil penelitian ini menunjukkan bahwa kompensasi berpengaruh secara positif dan signifikan terhadap kepuasan kerja karyawan, lingkungan kerja berpengaruh secara positif dan signifikan terhadap kepuasan kerja karyawan.

Kata kunci : kompensasi, lingkungan kerja, kepuasan kerja.

\section{LATAR BELAKANG}

Pada tingkat persaingan dunia bisnis saat ini, perusahaan tidak hanya harus menghadapi persaingan pada produk tapi juga persaingan dalam sumber daya manusia. Sumber daya manusia merupakan suatu asset yang dianggap penting dalam sebuah perusahaan. Keunggulan yang dimiliki sumber daya manusia yaitu adanya kemampuan potensi yang dimilikinya. Dengan adanya kemampuan potensi yang dimiliki oleh sumber daya manusia dapat mempengaruhi upaya perusahaan dalam mencapai tujuan. Keberhasilan suatu perusahaan dalam mempertahankan karyawan yang dimiliki tidak dapat dilakukan dengan mudah. Salah satu faktor yang dapat menentukan kelangsungan hidup karyawan atau tidak dalam suatu perusahaan adalah kepuasan kerja. Kepuasan kerja adalah perbedaan antara jumlah penghargaan yang diterima oleh seorang karyawan dan jumlah imbalan yang diyakini diterima. Memberikan kepuasan kerja kepada karyawan bukanlah suatu pekerjaan yang mudah bagi perusahaan. Perusahaan harus mampu memahami kebutuhan karyawan dan menciptakan lingkungan kerja yang kondusif sehingga dapat memberikan kepuasan kerja bagi karyawan dan termotivasi secara optimal. Salah satu cara yang dapat meningkatkan kepuasan kerja karyawan adalah dengan 
pemberian kompensasi. Kompensasi penting bagi karyawan karena jumlah kompensasi yang diberikan disesuaikan dengan besarnya pekerjaan yang dilakukan. Kompensasi umumnya ditujukan untuk kepentingan perusahaan dan karyawan. Selain kompensasi, faktor yang perlu diperhatikan juga oleh perusahaan adalah lingkungan kerja. Lingkungan kerja dapat mempengaruhi kepuasan kerja karyawan, di mana karyawan tidak akan dapat melakukan pekerjaan seperti yang diharapkan tanpa didukung oleh lingkungan kerja yang baik. Kenyamanan karyawan dalam melakukan pekerjaan sehari-hari tergantung pada lingkungan tempat mereka bekerja.

\section{KAJIAN TEORI}

Gambaran umum teori. Menurut Hasibuan (2011) Manajemen adalah ilmu dan seni mengatur proses pemanfaatan sumber daya manusia dan sumber - sumber lainnya secara efektif dan efisien untuk mencapai suatu tujuan tertentu.

Menurut Mondy. R. Wayne (2016) mendefinisikan manajemen sumber daya manusia sebagai "Human resource management (HRM) is utilization of individuals to achieve organizational objectives." Dari definisi tersebut Manajemen sumber daya manusia adalah pemanfaatan individu untuk mencapai tujuan organisasi.

Kompensasi. Menurut (Dessler, 2007) Kompensasi adalah semua bentuk pembayaran atau hadiah yang diberikan kepada karyawan dan muncul dari pekerjaan mereka (Dessler, 2007). Tujuan pemberian kompensasi menurut (Hasibuan, 2014) yaitu:

1. Ikatan Kerja Sama

2. Kepuasan Kerja

3. Pengadaan Efektif

4. Motivasi

5. Stabilitas Karyawan

6. Disiplin

7. Pengaruh Serikat Buruh

8. Pengaruh Pemerintah

Lingkungan Kerja. Menurut (Sofyandi, 2008) Lingkungan Kerja merupakan serangkaian faktor yang mempengaruhi kinerja dari fungsi-fungsi atau aktivitas-aktivitas manajemen sumber daya manusia yang terdiri dari faktor-faktor internal yang bersumber dari dalam organisasi. Faktor-faktor dalam lingkungan kerja menurut (Sedarmayanti, 2001) yaitu: (1) Penerangan atau Cahaya di Tempat Kerja, (2) Temperatur di Tempat Kerja, (3) Kelembaban di Tempat Kerja, (4) Sirkulasi Udara di Tempat Kerja, (5) Kebisingan di Tempat Kerja, (6) Getaran Mekanis di Tempat Kerja, (7) Bau tidak sedap di Tempat Kerja, (8) Tata Warna di Tempat Kerja, (9) Dekorasi di Tempat Kerja, (10) Musik di Tempat Kerja, (11) Keamanan di Tempat Kerja.

Kepuasan Kerja. Menurut (Robbins and Judge, 2015) mendefinisikan kepuasan kerja sebagai "job satisfaction is a positive feeling about the job resulting from an evaluation of its characteristic." Kepuasan kerja adalah suatu perasaan positif tentang pekerjaan, yang dihasilkan dari suatu evaluasi pada karakteristik-karakteristiknya. Dimensi dalam kepuasan kerja menurut (Luthans, 2006) yaitu: (1) Pekerjaan itu sendiri, (2) Pembayaran, (3) Promosi, (4) Pengawasan (Supervisi), (5) Rekan kerja. 
Hubungan antar variabel. Pengaruh antara kompensasi (X1) terhadap kepuasan kerja (Y) (Fauzi, 2017) melakukan penelitian di PT. Tor Ganda Medan, yang merupakan perusahaan perkebunan kelapa sawit di Medan. Hasil dari penelitian ini adalah kompensasi memiliki pengaruh yang positif dan signifikan terhadap kepuasan kerja karyawan pada PT. Tor Ganda Medan

Pengaruh lingkungan kerja (X2) terhadap kepuasan kerja (Y) (Juliarti, Agung, \& Sudja, 2018) melakukan penelitian pada 65 karyawan yang bekerja pada PT. Paramitha Auto Graha (Bengkel PAG). Hasil dari penelitian ini adalah lingkungan kerja berpengaruh positif dan signifikan terhadap kepuasan kerja karyawan pada PT. Paramitha Auto Graha (PT. PAG).

Kerangka pemikiran. Dalam penelitian ini dijelaskan mengenai variabel dari kompensasi dan lingkungan kerja yang mempengaruhi kepuasan kerja, maka dapat digambarkan sebuah kerangka pemikiran sebagai berikut:

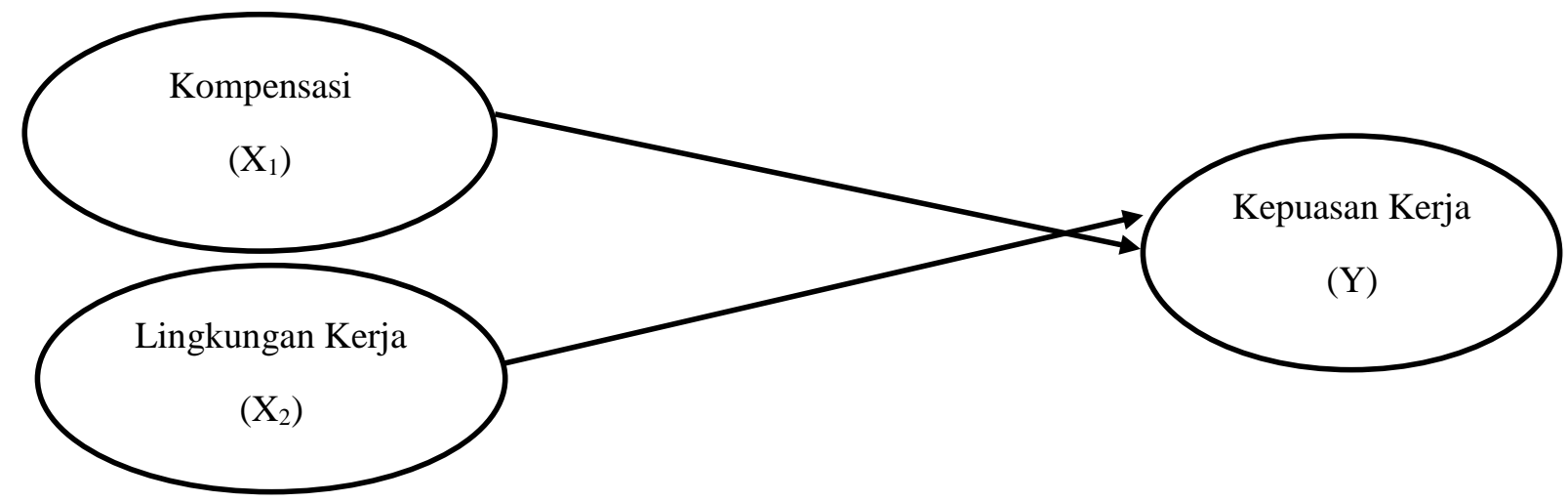

Gambar 1. Kerangka Pemikiran

\section{Hipotesis}

$\mathrm{H}_{1}$ : Terdapat pengaruh kompensasi terhadap kepuasan kerja.

$\mathrm{H}_{2}$ : Terdapat pengaruh lingkungan kerja terhadap kepuasan kerja.

\section{METODE PENELITIAN}

Objek penelitian ini adalah perusahaan PT. Temara Mas Sakti. Dalam penelitian ini yang menjadi populasi adalah 50 karyawan di PT. Temara Mas Sakti. Menurut (Sekaran \& Bougie, 2013) penelitian deskriptif ialah penelitian yang mendeskripsikan karakteristik dari orang, keadaan, maupun situasi. Teknik pemilihan sampel yang digunakan dalam penelitian ini adalah dengan metode sampling jenuh. Sampling jenuh adalah teknik penentuan sampel bila semua anggota populasi dijadikan sampel (Sugiyono, 2014). Teknik pengumpulan data untuk penelitian ini adalah dengan menggunakan kuesioner dengan skala Likert. Kuesioner diadaptasi dari: kompensasi (Mondy, 2016), lingkungan kerja (Nitisemito, 1992), dan kepuasan kerja (Luthans, 2006). Dalam penelitian ini menggunakan metode analisis Structural Equation Modelling (SEM) dengan program SmartPLS. Uji validitas, uji reliabilitas, uji koefisien determinasi, uji validity redundancy, dan uji Path Coefficient digunakan untuk mengukur tiap variabel yang terkait. 
Deskripsi Subjek Penelitian. Pada penelitian ini diketahui bahwa karakteristik responden terbanyak adalah responden dengan jenis kelamin laki-laki, yaitu sebesar 60\%. Dilanjutkan dengan karakteristik responden terbanyak melalui usia dengan jangkauan usia sekitar 2125 tahun sebesar 56\%. Kemudian karakteristik responden terbanyak melalui pendidikan dengan pendidikan terakhir sma/smk sebesar 56\%. Dan karakteristik responden terbanyak melalui masa kerja dengan rentan waktu 1-5 tahun sebesar 52\%.

\section{Hasil Uji Validitas}

Tabel 1. Hasil Uji Validitas Konvergen (Average Variance Extracted)

\begin{tabular}{|l|c|}
\hline \multicolumn{1}{|c|}{ Variabel } & Average Variance Extracted (AVE) \\
\hline Kompensasi & 0.519 \\
\hline Lingkungan Kerja & 0.518 \\
\hline Kepuasan Kerja & 0.514 \\
\hline
\end{tabular}

Sumber: Pengolahan Data SmartPLS, 2019

Berdasarkan tabel 1, nilai yang tertera pada Average Variance Extracted (AVE) dari setiap variabel lebih besar dari 0,5 sehingga hasil analisis validitas konvergen (AVE) dapat disimpulkan bahwa seluruh variabel penelitian telah memenuhi syarat kelayakan uji validitas konvergen dan dapat dikatakan seluruh variabel tersebut dapat menjelaskan selisih indikatornya sebesar atau lebih dari $50 \%$.

Tabel 2. Uji Validitas Diskriminan (Cross Loadings)

\begin{tabular}{|l|c|c|c|}
\hline & KK & K & LK \\
\hline K1 & 0.450 & $\mathbf{0 . 7 7 4}$ & 0.495 \\
\hline K10 & 0.504 & $\mathbf{0 . 7 4 4}$ & 0.469 \\
\hline K2 & 0.531 & $\mathbf{0 . 7 2 8}$ & 0.366 \\
\hline K3 & 0.544 & $\mathbf{0 . 7 3 3}$ & 0.438 \\
\hline K4 & 0.428 & $\mathbf{0 . 6 9 1}$ & 0.244 \\
\hline K5 & 0.494 & $\mathbf{0 . 7 1 3}$ & 0.471 \\
\hline K6 & 0.626 & $\mathbf{0 . 7 4 9}$ & 0.571 \\
\hline K7 & 0.468 & $\mathbf{0 . 7 4 1}$ & 0.341 \\
\hline K8 & 0.398 & $\mathbf{0 . 6 9 5}$ & 0.342 \\
\hline K9 & 0.399 & $\mathbf{0 . 6 2 5}$ & 0.319 \\
\hline KK1 & $\mathbf{0 . 7 7 1}$ & 0.442 & 0.444 \\
\hline KK10 & $\mathbf{0 . 7 8 9}$ & 0.503 & 0.616 \\
\hline KK2 & $\mathbf{0 . 6 5 7}$ & 0.555 & 0.267 \\
\hline KK3 & $\mathbf{0 . 7 6 8}$ & 0.495 & 0.493 \\
\hline KK4 & $\mathbf{0 . 7 8 8}$ & 0.599 & 0.439 \\
\hline KK5 & $\mathbf{0 . 6 2 9}$ & 0.338 & 0.284 \\
\hline KK6 & $\mathbf{0 . 6 1 1}$ & 0.509 & 0.136 \\
\hline KK7 & $\mathbf{0 . 7 0 5}$ & 0.523 & 0.462 \\
\hline KK8 & $\mathbf{0 . 7 1 8}$ & 0.491 & 0.460 \\
\hline
\end{tabular}




\begin{tabular}{|l|l|l|l|}
\hline KK9 & $\mathbf{0 . 7 0 8}$ & 0.393 & 0.426 \\
\hline LK1 & 0.412 & 0.441 & $\mathbf{0 . 7 4 0}$ \\
\hline LK10 & 0.353 & 0.464 & $\mathbf{0 . 6 1 8}$ \\
\hline LK2 & 0.445 & 0.433 & $\mathbf{0 . 7 8 5}$ \\
\hline LK3 & 0.351 & 0.351 & $\mathbf{0 . 7 5 7}$ \\
\hline LK4 & 0.512 & 0.462 & $\mathbf{0 . 7 4 4}$ \\
\hline LK5 & 0.468 & 0.540 & $\mathbf{0 . 7 0 5}$ \\
\hline LK6 & 0.302 & 0.335 & $\mathbf{0 . 6 6 5}$ \\
\hline LK7 & 0.426 & 0.371 & $\mathbf{0 . 7 5 9}$ \\
\hline LK8 & 0.492 & 0.372 & $\mathbf{0 . 7 5 0}$ \\
\hline LK9 & 0.270 & 0.306 & $\mathbf{0 . 6 5 3}$ \\
\hline
\end{tabular}

Catatan: Kompensasi (K), Lingkungan Kerja (LK), Kepuasan Kerja (KK)

Sumber: Pengolahan Data SmartPLS, 2019

Pada tabel 2, nilai loadings masing - masing indikator dari suatu konstruk lebih tinggi daripada nilai cross loadings indikator tersebut dalam konstruk lainnya. Sehingga dapat disimpulkan bahwa seluruh indikator masing-masing variabel telah memenuhi syarat kelayakan uji validitas diskriminan.

\section{Hasil Uji Reliabilitas}

Tabel 3. Uji Reliabilitas (Cronbach's Alpha \& Composite Reliability)

\begin{tabular}{|l|c|c|}
\hline \multicolumn{1}{|c|}{ Variabel } & $\begin{array}{c}\text { Cronbach's } \\
\text { Alpha }\end{array}$ & $\begin{array}{c}\text { Composite } \\
\text { Reliability }\end{array}$ \\
\hline Kompensasi & 0.897 & 0.915 \\
\hline Lingkungan Kerja & 0.896 & 0.914 \\
\hline Kepuasan Kerja & 0.894 & 0.913 \\
\hline
\end{tabular}

Sumber: Pengolahan Data SmartPLS, 2019

Pada tabel 3 menunjukkan bahwa nilai cronbach's Alpha dari setiap variabel mempunyai nilai cronbach's alpha lebih besar dari 0,6. Sehingga dapat disimpulkan bahwa semua variabel memiliki tingkat reliabilitas yang baik. Nilai Composite Reliability dari setiap variabel mempunyai nilai composite reliability lebih besar dari 0,7 . Sehingga dapat disimpulkan bahwa semua variabel memiliki tingkat realibilitas yang tinggi.

\section{Uji Koefisien Determinasi (R-Square)}

Tabel 4. Koefisien Determinasi

\begin{tabular}{|c|c|}
\hline Variabel & R Square \\
\hline Kepuasan Kerja & 0,517 \\
\hline
\end{tabular}

Sumber: Pengolahan Data SmartPLS, 2019

Berdasarkan tabel 4, menunjukkan nilai $\mathrm{R}^{2}$ kepuasan kerja sebesar 0,517 yang berarti variabel yang mempengaruhi (kompensasi dan lingkungan kerja) memiliki pengaruh yang sedang terhadap variabel yang dipengaruhi (kepuasan kerja). Sehingga 
dapat disimpulkan jika variabel kepuasan kerja dapat dijelaskan oleh variabel kompensasi dan lingkungan kerja sebesar 51,7\%, sedangkan sisanya 48,3\% dapat dijelaskan oleh variabel lain.

Uji $Q$-Square $\left(Q^{2}\right)$

Tabel 5. $Q$-Square $\left(Q^{2}\right)$

\begin{tabular}{|l|c|c|c|}
\hline & SSO & SSE & $\mathbf{Q}^{\mathbf{2}}$ (=1-SSE/SSO) \\
\hline Kompensasi & 500.000 & 500.000 & \\
\hline Lingkungan Kerja & 500.000 & 500.000 & \\
\hline Kepuasan Kerja & 500.000 & 386.778 & 0.226 \\
\hline
\end{tabular}

Sumber: Pengolahan Data SmartPLS, 2019

Berdasarkan hasil pengukuran $Q$-Square $\left(Q^{2}\right)$ yang ada pada tabel 5, diperoleh nilai $\mathrm{Q}^{2}$ sebesar 0,226 untuk kepuasan kerja. Hal ini menunjukkan nilai $Q^{2}$ lebih dari 0 yang berarti model penelitian dapat memprediksi setiap indikator pada variabel dependen. Sehingga dapat disimpulkan bahwa nilai $Q^{2}$ variabel kepuasan kerja sebesar 0,226 yang berarti variabel yang mempengaruhi kepuasan kerja memiliki tingkat relevansi prediktif.

\section{Hasil Uji Path Coefficient}

Tabel 6. Hasil Uji Path Coefficient

\begin{tabular}{|l|c|c|c|}
\hline \multicolumn{1}{|c|}{ Variabel } & Original Sample & T-Statistics & P-Values \\
\hline $\mathrm{K} \rightarrow \mathrm{KK}$ & 0.525 & 3,818 & 0.000 \\
\hline $\mathrm{LK} \rightarrow \mathrm{KK}$ & 0.276 & 2,226 & 0.026 \\
\hline
\end{tabular}

Catatan: Kompensasi (K), Lingkungan Kerja (LK), Kepuasan Kerja (KK)

Sumber: Pengolahan Data SmartPLS, 2019

Hasil pada Tabel 6 terdapat uji path coefficient yang menunjukkan kompensasi terhadap kepuasan kerja memiliki nilai koefisien jalur sebesar 0,525 , nilai t-statistik sebesar 3,818 lebih besar dari t-tabel, dimana t-tabel adalah 1,96 dengan tingkat signifikansi sebesar 5\% dan nilai p-values sebesar 0,000 lebih kecil dari 0,05 ( $p$-values < 0,05). Sehingga dapat disimpulkan bahwa variabel kompensasi berpengaruh positif dan signifikan terhadap variabel kepuasan kerja.

Kemudian lingkungan kerja terhadap kepuasan kerja memiliki nilai koefisien jalur sebesar 0,276, nilai t-statistik sebesar 2,226 lebih besar dari t-tabel adalah 1,96 dengan tingkat signifikansi sebesar 5\% dan nilai p-values sebesar 0,026 lebih kecil dari 0,05 ( $p$ vaues $<0,05$ ). Sehingga dapat disimpulkan bahwa variabel lingkungan kerja berpengaruh positif dan signifikan terhadap variabel kepuasan kerja

\section{DISKUSI}

Penelitian ini menyatakan bahwa kompensasi dan lingkungan kerja terhadap kepuasan kerja menghasilkan hasil positif dan signifikan. Kompensasi yang sesuai dan lingkungan kerja yang mendukung akan dapat meningkatkan kepuasan kerja karyawan. Kompensasi yang sesuai akan meningkatkan kepuasan kerja karyawan. Dengan demikian, 
kompensasi yang sesuai dapat mendukung peningkatkan kerja karyawan tepat waktu dan efektif. Lingkungan kerja yang mendukung dan sesuai dengan kondisi yang dibutuhkan karyawan akan meningkatkan kepuasan kerja karyawan. Dengan demikian, karyawan dapat bekerja dengan lebih nyaman dan pekerjaan akan menjadi cepat selesai.

\section{PENUTUP}

Berdasarkan hasil analisis data dan pembahasan yang dilakukan atas penelitian pengaruh kompensasi dan lingkungan kerja terhadap kepuasan kerja karyawan pada PT. Temara Mas Sakti dengan menggunakan analisis SEM-PLS, maka dapat diambil kesimpulan sebagai berikut:

1. Hasil penelitian ini menunjukkan bahwa 51,7\% variasi variabel dependen kepuasan kerja karyawan dapat dijelaskan oleh variabel independen yaitu kompensasi dan lingkungan kerja. Sedangkan sisanya sebesar 48,3\% dapat dijelaskan oleh variabel lain.

2. Terdapat pengaruh positif dan signifikan antara kompensasi terhadap kepuasan kerja karyawan pada PT. Temara Mas Sakti di Jakarta. Artinya semakin tinggi kompensasi yang diberikan perusahaan maka kepuasan kerja karyawan akan semakin tinggi. Sebaliknya, jika kompensasi yang diberikan perusahaan semakin rendah maka kepuasan kerja karyawan semakin rendah.

3. Terdapat pengaruh positif dan signifikan antara lingkunan keja terhadap kepuasan kerja karyawan pada PT. Temara Mas Sakti di Jakarta. Artinya semakin baik kondisi lingkungan kerja yang disediakan perusahaan, maka kepuasan kerja karyawan akan semakin tinggi. Sebaliknya, jika semakin tidak baik kondisi lingkungan kerja yang disediakan perusahaan maka kepuasaan kerja karyawan akan semakin rendah.

Saran. Berdasarkan hasil yang diperoleh dari analisis yang telah dilakukan, maka peneliti akan memberikan saran sebagai masukan yang sekiranya dapat bermanfaat bagi perusahaan dan peneliti lainnya yaitu sebagai berikut:

a. Pemberian kompensasi yang baik memberikan pengaruh positif terhadap kepuasan kerja karyawan, sehingga perusahaan disarankan agar untuk mempertahankan dan meningkatkan pemberian kompensasi baik yang berupa finansial maupun non-finansial.

b. Lingkungan kerja yang sudah baik memberikan pengaruh positif terhadap kepuasan kerja karyawan, oleh karena itu, perusahaan harus tetap mempertahankan bahkan meningkatkan kondisi lingkungan kerja menjadi lebih baik lagi demi mendukung pelaksanaan pekerjaan karyawan.

c. Bagi peneliti selanjutnya dapat memperdalam lagi tentang kompensasi dan lingkungan kerja terhadap kepuasan kerja karyawan dengan menjelaskannya lebih dalam lagi.

d. Bagi peneliti selanjutnya dapat menambahkan atau menggunakan variabel lain yang dapat mempengaruhi kepuasan kerja karyawan yang tidak diteliti dalam penelitian ini seperti: motivasi, kinerja karyawan, budaya organisasi, gaya kepemimpinan dan lainnya sehingga dapat memberikan hasil yang jauh lebih baik. 


\section{DAFTAR PUSTAKA}

Dessler, Gary. (2007). Manajemen Sumber Daya Manusia. Edisi Kesepuluh jilid 2. Jakarta: PT. Indeks.

Fauzi. (2017). Pengaruh Kompensasi dan Lingkungan Kerja Terhadap Kepuasan Kerja Karyawan PT. Tor Ganda Medan. Jurnal Riset Manajemen \& Bisnis (JRMB), 2 (3), 36-47.

Hasibuan, Malayu. S. P. (2011). Manajemen Dasar,Pengertian, dan Masalah. Jakarta: CV. Haji Masagung.

Aksara.

Juliarti, Putu. A. D., Agung, Anak. A. P., \& Sudja, I. N. (2018). The Effect of Compensation and Work Environment on Employee Performance with Employee Job Satisfaction as an Intervening Variable. International journal of Contemporary Research and Review, 9 (3), 20553-20562.

Luthans, Fred. (2006). Perilaku Organisasi. Edisi ke-10. Yogyakarta: PT. Andi

Mondy, R. Wayne. \& Martocchio, Joseph. J. (2016). Human Resource Management. Fourteenth Edition Global Edition. London: Pearson Education Limited.

Pawirosumarto, Suharno., Sarjana, P. K., \& Gunawan, R. (2017). The Effect of Work Environment, Leadership Style, and Organizational Culture towards Job Satisfaction and its implication towards Employee Performance in Parador Hotels and Resorts, Indonesia. International Journal of Law and Management, 59 (6), 1337-1358.

Robbins, S. P and Judge, T. A. (2015). Organizational Behavior. Sixteenth Edition. New Jersey: Pearson Education, Inc.

Sedarmayanti. (2001). Sumber Daya Manusia dan Produktifitas Kerja. Bandung: Mandar Maju.

Sofyandi, Herman. (2008). Manajemen Sumber Daya Manusia. Edisi Pertama. Yogyakarta: Graha Ilmu.

Sugiyono. 2014. Metode Penelitian Pendidikan Kuantitatif dan Kualitatif dan $R \& D$. Bandung: CV Alfabeta. 